\title{
Teaching Future Teachers in the Subject of Pedagogy
}

\author{
Liv Gjems (Corresponding author)
}

Faculty of Education and the Humanities

Buskerud and Vestfold University College

P.O.Box 235, 3603 Kongsberg, Norway

Tel: 47-3100-9171Ｅ-mail: liv.gjems@hbv.no

\author{
Inge Vinje \\ Faculty of Education and the Humanities \\ Buskerud and Vestfold University College \\ P.O.Box 235, 3603 Kongsberg, Norway
}

Tel: 47-3100-9238Ｅ-mail: inge.vinje@hbv.no

Received: April 12, 2015 Accepted: May 7, 2015 Published: May 12, 2015

doi:10.5296/jei.vli1.7591 URL: http://dx.doi.org/10.5296/jei.v1i1.7591

\begin{abstract}
In several European countries, teacher education is regulated by national plans that emphasise pedagogy as the central subject. Pedagogy shall include research-based knowledge, as well as having a strong connection between theory and practice. We have interviewed teacher educators about what they emphasise about theoretical and practical issues in the subject of pedagogy. Though they have to follow the curriculum, they express that they have different conceptions and emphasise different issues both in theoretical and practical pedagogy. Their answers point to the challenges between the establishment of a professional autonomy and the control the national curriculum imposes them The teacher educators were quite vague about their teaching about research-based knowledge. They expressed that they need support, time and possibilities to discuss the content in the curriculum and how to educate high qualified teachers.
\end{abstract}

Keywords: Teacher educators, Pedagogical knowledge, Reflection, Research-based pedagogical knowledge 


\section{Introduction}

The aim of this study is to examine the areas that teacher educators emphasise when teaching future teachers the subject of pedagogy. There is worldwide agreement among politicians that the single most important strategy for achieving the educational goals which we all strive to achieve is the preparation of, and support for, excellent teachers in all schools. However, despite political agreement regarding the importance of focusing on teacher education, the responsibility for preparing qualified and competent teachers rests primarily with national and local teacher education programmes, as well as with the teacher educators at teacher university colleges. As a consequence, teacher educators - those who teach future teachers - are central to educational reforms of all kinds. Nevertheless, despite the wealth of commentary on teacher education, little empirical research has focused on the teacher educators themselves (Korthagen, 2000).

In the last decade in Europe, the national curriculums for teacher education have emphasised the importance of research skills (Grossman, Hammerness, McDonald, \& Ronfeldt, 2008). However, few detailed guidelines are usually given to teacher educators regarding how to teach research skills in their pedagogical work with education students. In addition, according to Grossman et al. (2009), in their education of future teachers, many teacher educators experience a problem to clarify the connection between theoretical knowledge and teachers' practical work in classrooms.

In this study, we will examine what teacher educators emphasise as the central aspects of the curriculum in the subject field of pedagogy. We will focus primarily on what they emphasise when teaching about the theoretical and practical elements of pedagogy, as well as the research-based knowledge in this field. Pedagogical theory describes and discusses education and teaching and illuminate the relation between these activities and the individual person, society and culture. Practical pedagogy is about education and teaching to adapt for learning. The subject of pedagogy has been chosen because it is essential to working with students from preschools to high schools (Murray \& Male, 2005). In teacher education, local university colleges and teacher educators can make many important decisions about what and how to teach. We ask the following research questions:

What do teacher educators in the subject of pedagogy emphasise in their education of future teachers?

\section{How do they teach about research-based knowledge?}

Teacher educators are models for methods of teaching, and they represent future teachers' ideals and values regarding how to teach. However, their conceptions about teaching and pedagogical work have received minimal research attention (Grossman, Hammerness, \& McDonald, 2008). Several researchers have pointed to the underlying causes of the theory-practice divide (Lunenberg \& Korthagen, 2009). Teacher education lies in the area between theory and practice, which is a dilemma that educators have to solve. Evidence exists that the acquisition of professional teacher competence is influenced by the ways in which this linkage is accomplished (Blömeke, Felbrich, Müller, \& Lehmann, 2008). 
In Norway, as in several European countries, teacher education is regulated by a national curriculum that emphasises pedagogy as the main subject areas throughout the whole course of study. Alongside this is the importance of research-based knowledge and the solid connection between theory and practice. Therefore, Norway faces many of the challenges that confront researchers in other countries. Norwegian teacher education may, thus, represent some of the essential challenges facing teacher education in many countries. In this article, we will present the results of three focus group interviews with teacher educators working in three different teacher colleges. Each group consists of four informants.

\subsection{The Norwegian Context}

Pedagogy is the dominant subject in all types of teacher education in Norway. Therefore, education in pedagogy influences all the other subjects in the education of future teachers. Pedagogy is 'the formatting platform education students need both through the education and for professional pedagogical practice in the future' (Ministry of Education and Research, 2009, p.22). Pedagogy aims, among other things, to strengthen the education teachers' closeness to practical work and their orientation towards research. Furthermore, pedagogy ensures the completeness and coherence of the education students' qualifications.

Pedagogy builds on science-based content related to teaching, learning, and education, and it includes theory, as well as research and practice. In addition, the National Curriculum underscores the importance of reflection upon intentions, choices, and actions, as well as giving reasons for them. In Norway, we have little research about how teacher educators are preparing education students to reflect on both theoretical and practical work.

As in many other countries, pedagogy in Norwegian teacher education represents the platform the profession is based upon (Bennet, 2007; Korthagen, 2004).

\subsection{Research and Development-Based Knowledge in Teacher Education}

According to the Norwegian government, teacher educators should teach education students theoretical and research-based knowledge, as well as how to teach and work with children and youth (Norwegian Organ for Quality in Education (NOKUT), 2010). Heggen and Smedby (2012) argue that the demands for research-based knowledge have increased in Norway, as well as in other countries in Europe and the United States (US). Research-based teacher education is the main approach to teacher education programmes in many Western countries (Zeichner \& Conklin, 2008). A central aim within these programmes is to educate inquiry-oriented future teachers.

According to Grythe (2011), research-based knowledge can be defined as teaching about the content and processes for achieving research results. The Ministry of Education and Research (2005) claims that the Norwegian universities and university colleges 'offer higher education based on the foremost within research, professional work and aesthetical innovation and experience based knowledge'. However, Lid (2012) finds that this principle is understood and put into practice in different ways. He finds that most understandings and definitions are built on research and teaching, where the teaching of research is about results from former research projects. Only a few teacher education institutions relate research and development 
(R\&D) to education (ibid. 2012). Contrastingly, the Norwegian Association of Researchers' own definition of R\&D-based education focuses on the teacher educators' own research contributions, their research competence, and their use of current and updated research in their teaching (Lid, 2012). The focus is on the competent researcher as educator. The NOKUT (2010) has a broader and slightly different understanding of R\&D and emphasises the importance of teacher education that focuses on the kind of R\&D knowledge that future teachers will need in their pedagogical work. The Norwegian Association of Researchers focus to a lesser degree on the knowledge that future teachers need to have to work in preschools and schools. Contrastingly, Grythe (2011) argues that research-based education should include research about how teachers will teach in their own classrooms.

\subsection{Theory and Relevant Research}

International research has pointed out the disparities between the multiple demands placed on teacher educators and the lack of attention given to this group, as well as to the policies that would support their ongoing learning. Korthagen (2000) suggests that teacher educators have long been a neglected group in the Netherlands, and according to Smeby (2007), the same is true of Norway. Even so, politicians and the teachers groups themselves expect that teacher educators are carrying out national educational reforms. Cochran-Smith (2007) notes that teacher educators in the US are charged with preparing teachers to use new curriculum standards, teach computer literacy, and include technology in all subject areas. In Norway, major reforms have been undertaken in preschools and schools. Teacher educators have been obliged to prepare education students to adhere these reforms as the standards in their future work. In addition, local politicians and teachers expect teacher educators to teach practising teachers about how to meet and to discuss possible new demands. The teacher educators themselves receive little or no support in regard to their efforts to study and acquire knowledge about these reforms or to discuss their consequences.

Teacher educators are exposed to the demands and constraints associated with both globalisation and professionalisation. The Programme for International Student Assessment (PISA) pressure on schools and teachers affects teacher educators in terms of what and how they will teach future teachers and influences both the national and the local curriculums.

According to the research that has been conducted on curriculums (Ben-Peretz, 2001), they not only represent a science that is focused upon solutions, but they are also followed step by step. Ben-Peretz (1990) and Bjørnsrud (2005) emphasise that teacher educators and teachers must be able to locate pedagogical spaces to interpret and experiment with different understandings and actions in the curriculums. The research underscores that a curriculum represents a text that cannot be limited to prescribed actions and goal-directed teaching (Ben-Peretz, 2001).

During the last decade, in addition to theory and practice, the subject of research-based knowledge has been added to the curriculums. As a teacher educator in pedagogy at the university and university college levels, one faces the challenge involved in working as both a practitioner and a researcher and combining theories and research-based knowledge with practical pedagogical knowledge. A teacher educator is thus both a user and a creator of 
knowledge. According to Blömeke et al. (2008), there is evidence that the acquisition of professional competence is influenced by the way in which this linkage is accomplished. Teacher educators have to question, challenge, connect, try out, revise, reshape, and critique the knowledge they use in the education of education students. To raise relevant questions and promote both theoretical and practical knowledge among education students, teacher educators should continuously raise questions about how research benefits the context of education. Cochran-Smith (2002) underlines that teacher educators ought to discuss the purposes of education, as well as the perspectives that are both represented in and missing from teacher education and the curriculum.

Teaching is a complex practice, and teacher educators in the field of pedagogy have to teach different future teachers content knowledge, as well as methodological and practical skills. In the eighties and nineties, emphasis was placed primarily on the knowledge that future teachers needed. Among others, Shulman (1986) attempted to differentiate the kind of specialised knowledge required for teaching that a well-educated person should have about a subject such as pedagogy. The emphasis on subject knowledge has covered the importance of other aspects of teaching related to the competence to plan, choose relevant methods, and carry out classroom activities and the relational work involved in creating learning communities in classrooms. However, in the last three decades, the views on teaching have evolved from an emphasis on teachers' subject knowledge to more recent cognitive views of teachers as decision-makers and reflective practitioners. According to Grossman et al. (2009), teacher education has responded to this final turn towards the cognitive focus by shifting its emphasis from skills to knowledge and reflection. Reflection involves a thinking process that leads to new understanding and knowledge, and is related to consideration and a retrospective glance. In the Norwegian national plan for teacher education, the importance of teachers' reflection is mentioned several times for all subjects, but especially in regard to the 'critical reflection' that is mentioned in the national plan for the subject of pedagogy.

Teacher educators are important models for prospective teachers, and they lay the foundation for how they learn to teach. As models, they represent values and beliefs about how and what to teach. According to Grossman et al. (2008), teacher educators are individuals who may emphasise, whether intentionally or not, different ways to prepare future teachers, focusing on theoretical and/ or research-based knowledge and/or on knowledge that is useful for practical work in the classroom. Even though they have a curriculum that they are obliged to follow, teacher educators can and have to make many of the decisions regarding what what to teach and how. According to Goodlad (1979), teacher education institutions can interpret the national curriculum and the qualification framework differently, although these must be in accordance with the national curriculum. In Norway, the interpreting and developing of the local curriculums, have to follow the Norwegian Qualification Framework for Higher Education (Department of Higher Education, 2011), which describes what knowledge, skills, and general competence an educated teacher should have. Nevertheless, there is room for local variations in the interpretations of how and what to choose to fulfil the aims outlined in the national curriculum (Goodlad, 1979). The education students will be educated in accordance with what their local educational institution and different teacher educators 
emphasise as the important knowledge and skills for pedagogical work in schools and preschools.

Swennen, Lunenberg, and Korthagen (2005) emphasise that teacher educators should have a fairly well developed knowledge of theories. They indicate that, most of all, teacher educators must be capable of concretising such theories for the education students in relation to their own actual teaching practice, as well as that of the students. In our analyses of the interviews conducted with teacher educators, we examine what they say about the knowledge, skills and general competence that are important for the development of future teachers' theoretical, research-based, and practical knowledge.

\section{Methodology}

In this study, we focused on how teacher educators at three university colleges for teacher education conceive of and emphasise the subject of pedagogy. Consequently, we did not include teachers with responsibility for the practical training of education students. We interviewed 12 informants in three focus groups from three university colleges. This is a small-scale study representing what 12 teacher educators from three university colleges perceive and experience as educators in pedagogy. The data may consist of questions that represent central issues for education of future teachers in Norway, and there is little research both national and international about these questions. The questions represent viewpoints and experiences that may be relevant for teacher educators from several university colleges, and they are in accordance with international studies (Cochran-Smith, 2002; Lunenberg \& Korthagen, 2009).

\subsection{Focus Group Interviews}

Focus group interviews are used as a source of data whereby the interaction between participants is expected to generate additional or different information from what can be obtained from individual interviews. The focus group approach was chosen because we do not search for certain pre-defined answers but want the focus groups to develop answers and understandings through dynamic interactions (Bloor, Frankland, Thomas, \& Robson, 2001). According to Stewart and Shamdasani (1990), focus group interviews are mainly used to gain knowledge of unexplored areas. Drawing on Malterud (2012), we chose to have focus groups with participants who had mainly had the same experiences, thereby enabling us to get to explore the informants' experiences and viewpoints on the subject of pedagogy and how they teach research-based knowledge. The argument for this method was that it would inspire the informants to think aloud and elaborate on their different points of view on this under-researched area. However, we do not know how they teach and how they present theory, research, or practical pedagogical knowledge to the education students; we have only their own utterances on the subject.

The three focus groups were selected from three university colleges located in three different regions in Norway: one in a medium large city, one in a small city, and one in a little village. The selection of university colleges was based on the assumption-which is also in keeping with our experience - that they usually recruit teacher educators who have been educated at 
different universities and university colleges throughout the country. In this way, we hoped that the informants would have varied experiences and values. The focus groups were composed of four teachers who had all been teacher educators for more than five years.

We formulated an interview guide that consisted of five open-ended questions, and these were sent to the informants a week prior to the group meeting. The questions were developed to get information about the informants' experiences and conceptions about what to teach the education students about pedagogical theories, research based pedagogical knowledge and how to work in schools. We asked the teacher educators what they perceive as the most important aspects of the subject of pedagogy in teacher education. We asked the same five questions in each of the three focus groups (Appendix 1). The participants engaged with each other and commented and expanded on one another's utterances. All the informants stated that they appreciated talking about their pedagogical knowledge, ideas, conceptions, and challenges for some time. We were the two moderators during the interviews.

In this article, we discuss the challenges and experiences that the 12 teacher educators indicated that they faced when meeting the demands of teaching practical, theoretical, and research-based knowledge to education students, as well as basic general knowledge regarding how to deal with classroom practice.

\subsection{Analysis}

The interviews were transcribed and analysed to determine how teacher educators conceive of the different aspects of the subject of pedagogy. We analysed the transcripts to identify common themes that emerged during their discussion concerning their teaching in the field of theory and pedagogical practice. We started by reading the interviews and identifying the subjects that all the informants mainly agreed were of primary importance in teacher education. We examined whether there was some disagreement in the three groups across the university colleges, and if so, in which fields. We then searched for which conceptions of pedagogy they expressed and whether these were shared across informants and university colleges. Finally, we examined what was said about research-based knowledge.

The analyses resulted in four categories across the five questions: In the first category, the informants mainly expressed common conceptions regarding how to teach future teachers about pedagogical practice. In the next two categories that emerged, the informants differed regarding what theoretical subjects are of primary importance. They also had different conceptions about the use of reflection when they are teaching about pedagogical theory. The fourth category pertained viewpoints about research-based knowledge. Below is the presentation of their central answers to the two research questions.

\section{Findings}

The findings are organised according to the four categories that resulted from the analysis. We begin by presenting the category in which many of the informants agreed and shared their conceptions. We then present the two categories in which there is more disagreement, and finally, we present the informants' perspectives on research-based knowledge in the subject of pedagogy. 


\subsection{How to Teach about Practical Pedagogical Knowledge}

All the informants agreed that pedagogy is the core of the professional perspective in teacher education. However, they also referred to pedagogy as an abstract field and stated that whether they succeeded in engaging the education students depended on how they presented examples and on the different exercises, they gave to the students, such as on how to start a lesson. In the discussions about how to concretise and present different professional tasks to the education students, one teacher educator stated, 'I think that we need many examples, and we need to know about the methods the students can use in different teaching situations. And, of course, we need them to know something about the actual children or pupils'. Most of the information the informants provided about how they teach the education students how to teach related to how they used examples. They all agreed that without examples, their teaching was poor.

One of the teacher educators declared that she uses different methods, and that, as an educator preparing for school, she conducts exercises in the education students' classrooms:

For instance, how can I teach them to divide the students into groups? They learn to use sex, height, or the kind of watch the pupils have. Or I teach them how to start a lesson. Then all of them have to leave the room, and then they practise how to start.

Another teacher educator stated that she gives examples of how to act in pedagogical practice, using both the education students' examples in addition to her own from pedagogical practice, and she discusses them with the education students.

The focus groups also discussed the balance between examples and the dangers of being instrumentalist. One informant stated, 'Some of my colleagues are terrified to use examples because they are afraid this will develop a kind of learning culture where the whole focus will be on educational techniques'. Another educator expressed a similar sentiment: 'I think that pedagogy is about the meeting between people and that, in my teaching, I must ask questions like "How do I use this theory to understand something in the classroom?" and then I use some examples'. She stated that she invites the students to recall examples from their practice periods and that she uses this approach when teaching about child development, play and formation, and theories of leadership. She also stated that she attempts to include practical examples in all her teaching. Throughout the interviews, the informants expressed different points of view about how to use examples in teaching. However, they all agreed that the use of examples is the best way to teach about pedagogical practice.

\subsection{How to Teach Theoretical Subjects}

When asked about what they think comprises important theoretical knowledge for education students, one teacher educator answered that she emphasises theories of learning, starting with traditional Skinnerian behaviourism and moving towards more modern theoretical perspectives, such as sociocultural theories: 'These theories are important for much of the pedagogical work with children. I think the learning theories represent the grounds for pedagogy'. All teacher educators in the three focus groups partly agree on the importance of learning theories; however, one informant underscored the importance of didactical theories 
for future teachers: 'I will absolutely give the education students knowledge about didactical theories; they are important tools for teachers'. One of the teacher educators added that certain theories are important in her teaching: '[They] can be theories about interaction, learning and language, and theories about basic pedagogical philosophy as well'. Another teacher educator emphasised that she believes that the most important thing to teach the educational students is how to work to support children's learning and to view children as people: 'I want the education students to promote children's learning, but not everything is about learning. To want to be a human, to participate in what happens ... this is part of the pedagogy I am engaged in'.

The teacher educators also emphasised another aspect of pedagogy. In response to the question about how they conceive of theories in their teaching, one educator stated that she always thinks of applicability and not only of theory and that this is because not all theory is applicable to practical pedagogical work with pupils. She stated, 'Many fields of theory are important in the subject of pedagogy, but they must have some connection to the work as a teacher and the many tasks you have to perform'. She underscored that she emphasises theories that the students can combine with pedagogical work in the classroom. This teacher educator also stated that she chooses not to use philosophical theories in teacher education.

In relation to theoretical subjects, they were also engaged in talking about the curriculum for pedagogy. One teacher educator stated, 'We are much more directed by this plan than by the former'. They agreed with much of the content, however, they would also like to have more influence on how to organise their teaching. One of the informants stated, 'I think, then, that the subject of pedagogy should be taught like a hermeneutic circle so that we could return to the same subjects more times but from some other angle'. The teacher educators in the other focus groups also said that they would like to have more freedom to choose what to teach and when.

In response to the question about the theoretical pedagogical subject, the teacher educators answered somewhat differently. However, all the teacher educators emphasised that theories of learning are important, and they expressed quite joint conceptions in this regard. They all expressed that they were obligated to follow the curriculum and teach the subjects it prescribed. At the same time, they said that they had the opportunity to use more time on subject they preferred; some emphasised humanism and the development of social skills as important in pedagogical theories, while others focused on applicability and theories related to didactic work. Still they wanted more freedom to choose the subjects they as individual educators perceived of as important.

\subsection{Perspectives on Reflection}

Throughout the analysis, it became apparent that when teacher educators were asked about what they thought was important in the teaching of pedagogy, they all talked about the importance of reflection as part of the education students' learning. They underlined that reflection was important to both the theoretical and practical pedagogical aspects of teacher education. They also all appreciated that the curriculum obliged them to teach the education students to use the theories of pedagogy to reflect upon their practice in their work as teachers. 
For example, one teacher educator stated that she combines theory and reflection and that, as educators, they are obliged to present theoretical concepts, realistic examples, and experiences. However, she also stated, 'We must, most of all, give them time to reflect together so that they can make connections [and] create discussions. The conversations and discussions will [lead to] more reflections [and] more questions'. This utterance was followed by nodding and agreement among the informants. After some seconds of silence, another teacher educator stated, 'I think of all the situations where we want them to reflect, reflect, and reflect. Why can't we sometimes give examples where we force the students to argue, give reasons, and then [we] encourage them to reflect?' This teacher educator communicated a concern about her work with reflection, and she conceived of it as quite a vague subject in the field of pedagogy. In another group, a teacher educator made similar comments about reflection: 'As a teacher educator, I have been educated and socialised not to be normative and [told] that reflection is important to use. When you can't present students with something as true, only reflection will work'. She declared that when one is obliged not to be normative, one can end up in another ditch: One can become too vague.

One teacher educator stated in regard to her conception of pedagogy that 'we shall give them theories and realistic examples, as well as experiences, as well as time to reflect together and discuss. The discussions and conversations we have in the classroom will lead to more reflection'. She stated that reflection is the aim of most of her teaching. In this way, some of the informants objected to the overuse of reflection in their teaching of pedagogy. One teacher educator stated, 'do we always solve the challenging educational situations by reflecting on something, or should we sometimes present examples where we force them to argue, give reasons, and then reflect afterwards?' One of the teacher educators stated:

'I agree that we are expected to be compassionate, to think and reflect. Of course, the "great" theories have a limited impact area as a basis for knowledge and reflection. This is not always enough; you have to use tools'.

Though the informants stated that they conceive of reflection as an important field, some of them also raise some critical thoughts.

\subsection{Perspectives on Educational Research-Based Knowledge}

When we asked about how they were able to work with the demands of teaching about research-based education, the informants described the different ways in which they understood this area. One stated, 'If what we mean by "research-based" is reading research reports and journal articles, I do not teach research-based areas'. This was not an answer but more of a question posed to the group; therefore, another informant in the group asked the others what 'research-based' meant: 'Does "research-based" mean that the education students should do research? When? When they are in the practical teaching periods, or what?' One of her colleagues answered this question: 'Yes, we mainly connect research-based education to practice periods in school. But, in the future, I think it will be excellent to relate it to the bachelor assignment'. This answer indicates that research-based education has been given less priority in this teacher university college and that the practical training teachers are responsible for teaching in this field. 
In one of the groups, one teacher educator stated, 'The education students must learn how to do research, because this is important for lifelong learning'. Another pointed to the importance of understanding the foundation of knowledge, stating, 'They have to learn why we know something and how we know it'. Yet another informant stated that, in her view, 'research-based' meant that her teaching was true and valid and not based solely on what she herself thought and meant: '[O]f course, I will have my own opinions, but I have to reveal what they are based on. And if one presents one's own research, it is of great importance to let the students know how knowledge is built'. This teacher talked about research in education as being honest and real, and the focus group accepted this.

In another group, one informant talked about the importance of evidence-based knowledge, stating, 'The subject of pedagogy is so normative, and I think we have to get more evidence-based perspectives on both theories of learning and different methods. It is only evidence-based knowledge that can give the students an understanding of what works'. No one in the group contradicted this viewpoint. One informant stated, 'An important part of the research-based subject is to give them (education students) updated knowledge, but this must also be a lifelong process. And they must be critical of knowledge'. Another informant stated, 'Throughout their education, I think we must use research-based knowledge to give the future teachers another understanding of their own practice. Yes, I think so'.

None of the other informants in the groups completed or expanded on such statements to indicate what they felt ought to be taught. All the teacher educators talked about research-based knowledge as something that the students should learn and what they have to know and to learn, and this was done without relating it to their own teaching. The informants mostly talked about research-based knowledge in quite general terms without defining or giving examples of what they do or want to do when teaching about research-based knowledge.

This category was difficult to analyse according to the informants' conceptions of what is important with regard to teaching future teachers. The informants had different conceptions of the content and consequences of research-based education and research in pedagogy; however, they all talked about teaching in the field of research-based pedagogical knowledge as if the education students would learn about this on their own or after completing their teacher education. None of them expressed directly that they have a responsibility as educators to lead the future teachers towards a certain kind of pedagogical research, nor did they appear to consider how they could use research as part of their own professional work. They mainly talked about what they should teach and what could be taught.

\section{Discussion}

Teacher educators have to connect the theories they teach in pedagogy to practical work. All the informants stated that they emphasised the importance of using examples to concretise pedagogical theory and discuss how to teach and work in educational settings. As teacher educators, they are models who represent values and beliefs regarding how to teach. However, according to Darling-Hammond, Hammerness, Grossman, Rust, and Shulman (2005), the model method depends on a thorough process of theorisation, discussion, and reflection. 
Without this thoroughness, this method of teaching how to teach will represent values and beliefs that are accepted without awareness. In the discussion about the use of examples, none of the informants raised any objections about this as a method to teach practical pedagogy. The question, however, is whether the education students will copy the examples without reflection. The informants emphasised examples as a positive way of teaching the practical side of pedagogy, however they never discussed what could be good examples and how to find them. However, they never elaborated on what such examples could be. A suggestion for further development of teacher education might be that excellent examples that can support teaching of pedagogical practice could be a subject of professional cooperation and sharing.

The subject of reflection is central in the National plan and was mentioned numerous times in relation to different questions and discussions about pedagogy. All the teacher educators acknowledged the importance of inviting the education students to reflect on pedagogical theories and practical experiences. However, there was some discussion in two of the groups about the danger of overusing reflection; it was felt that too much reflection can cause the teacher educators to give the education students a vague and uncertain knowledge base for teaching and working with students. According to these viewpoints, there is the possibility for reflection to be perceived and practised as a more important learning field than substantial pedagogical theories and knowledge. Some of the informants seemed to acknowledge the importance of reflection over theoretical knowledge. Reflection without thorough theoretical knowledge may, to a limited degree, lead solely to the development of understanding and practical pedagogical progresses (Smeby, 2011). Based on our data, an interesting finding is that the informants talked primarily about reflection without relating it to pedagogical theory. However, two of the teacher educators represented an exception: One pointed to the need to give examples that forced the students to argue and explain, and the other pointed to the danger of being too unclear. The Norwegian teacher educators seem to emphasise that reflection can promote much of their teaching of pedagogical theories and practical pedagogy. A relevant question may be what competence the future teachers will get for further development of knowledge and teaching if they do not develop a basic theoretical foundation.

The teacher educators from the three different university colleges expressed somewhat different conceptions of the central theoretical perspectives. They all agreed that theories of learning and theories about didactical work are of importance. However, they differed on the perspectives on the applicability of theories and a more philosophical view on the children as human beings. The teacher educators in the three focus groups agreed that they can make some decisions themselves regarding what to teach and how. In their education of teachers, the teacher educators emphasise theories they themselves prefer, without connecting their preferences to the knowledge base relevant for future teachers. May be teacher educators need to discuss how they can combine their individual theoretical preferences with the future teachers' global knowledge base.

The teacher educators mainly talked about research-based knowledge as updated knowledge without mentioning how this knowledge had been developed-that is, whether through research or processes that are more philosophical. They also stated that they had received little information from their university colleges and that they had not been invited to discuss 
and develop a deeper understanding of this subject area as a principle that they have been expected to deal with. All the informants talked about the importance of research-based knowledge as part of the future teachers' lifelong learning. They underlined the future teachers' needs for research-based knowledge. However, for the most part, the informants talked about research-based knowledge as if the students should learn about it without relating it to their own teaching. In this way, the teacher educators answered that they did not emphasise research-based knowledge as part of the theoretical or practical pedagogical education of future teachers. This is may represent an example of the need for time and support for teacher educators to discuss and develop understanding of the new reforms they are obliged to follow.

\section{Conclusion}

The informants in this study represent 12 teacher educators from three university colleges. The data from the interviews were limited to what they experienced, as well as to their conceptions and values. They pointed out that in several areas of teacher education, some subjects - such as the balance between theory and practice were challenging. They also exposed the dilemmas of freedom and control in education. Their experiences as teacher educators are in accordance with many of the findings of international studies (Korthagen, 2000; Lunenberg \& Korthagen, 2009)

According to Grossman, Hammerness, McDonald, and Ronfeld (2008), in the process of teaching future teachers about teaching, the teacher educators model the role of the teacher whether or not this is done consciously. Regarding the question of what conceptions they had about the subject of pedagogy in their teaching, the 12 teacher educators in this study had a number of different conceptions about the best ways to prepare future teachers in the subject of pedagogy. To some degree, they also differed in regard to what they saw as important for pedagogical knowledge and pedagogical work. They all stated that they appreciate the freedom to choose what and how to teach and that they would like to have even more freedom. It seems as if the national plan - the foundation for the local curriculum-has influenced the ways in which the teacher educators conceive of what is important to teach the future teachers and how to teach in the field of pedagogy.

This dilemma is an issue that is worthy of further examination; will different individual or private conceptions among teacher educators of what is important, relevant, and valuable, promote high quality in teacher education? If we allow too much freedom in regard to what and how to teach, we may lose the comprehensive knowledge base for teaching which many researchers recommend for preparing excellent teachers. At the same time, most of the teacher educators are well educated and experienced in both teaching and research, and forcing them to teach according to political ideals and goals will probably cause them to become less interested in their jobs. Teacher educators in pedagogy have a central role in the education of future teachers. They need both the time and opportunity as individuals and professional teacher teams to explore the different alternatives for understanding the content, values and actions related to the national curriculums. The challenge is to establish the balance between autonomy and central government control to promote more conscious 
conceptions of what future teachers' comprehensive knowledge base must comprise (Ben-Peretz, 1990; Bjørnsrud, 2005).

We interpret findings so that research-based education is rarely discussed in the professional communities at the three university colleges. They talk about the results of research rather than about the research processes. If the focus is on the teacher educators' as researchers and their own research, this will undermine the attention towards what kind of research-based knowledge the future teachers will need.

In conclusion, an important issue is to educate high quality future teachers. To do this, teacher educators need support, time and possibilities to discuss the content in the curriculum and study how to educate teachers according to the changing demands in shifting times.

\section{Acknowledgements}

This study is financed by the Norwegian Research Council.

\section{References}

Ben-Peretz, M. (1990). The Teacher-Curriculum Encounter. Freeing Teachers from the Tyrrany of Texts. Albany: State University of New York Press.

Ben-Peretz, M. (2001). The impossible role of teacher educators in a changing world. Journal of Teacher Education, 52(1), 48-56.

Bennet, J. (2007). New Policy Conclusions from Starting Strong II An Update on the OECD Early Childhood Policy Reviews. In S. O’Brien, P. Cassidy \& H. Schonfeld (Eds.), Vision into Practice - Making Quality a Reality in the Lives of Young Children (pp. 14-26). Dublin: Centre for Early Childhood Development and Education.

Bjørnsrud, H. (2005). Rom for aksjonslcering (Space for action learning). Oslo: Gyldendal Akademisk.

Bloor, M., Frankland, J., Thomas, M., \& Robson, K. (2001). Focus groups in social research. London: Sage.

Blömeke, S., Felbrich, A., Müller, G., \& Lehmann, R. (2008). Effectiveness of teacher education - State of research, measurement issues and consequences for future studies. ZDM Mathematics Education, 40, 719-734. http://dx.doi.org/10.1007/s11858-008-0096-x

Cochran-Smith, M. (2002). Learning and unlearning: the education of teacher educators. $\begin{array}{llll}\text { Teaching } \quad \text { and } & \text { Educher }\end{array}$ http://dx.doi.org/10.1016/S0742-051X(02)00091-4

Darling-Hammond, L., Hammerness, K., Grossman, P., Rust, F., \& Shulman, L. (2005). The Design of Teacher Education Programs. In L. Darling-Hammond \& J. Bransford (Eds.), Preparing Teachers for a Changing World. What Teachers should Learn and Be Able to Do (pp. 390-441). Jossy Bass, Whiley.

Department of Higher Education. (2011). National Qualification Framework. Oslo. 
Goodlad, J. (Ed.). (1979). Curriculum Inquiry. The Study of Curriculum Practice. New York: McGraw-Hill Book Company.

Grossman, P., Hammerness, K., \& McDonald, M. (2009). Redefining teacher: Re-imagining teacher education. Teachers and teaching: Theory and practice, 15(2), 273-290. doi:10.1080/13540600902875340

Grossman, P., Hammerness, K., McDonald, M., \& Ronfeldt, M. (2008). Constructing Coherence - Structural Predictors of Perceptions of Coherence in NYC Teacher Education Programs. Journal of Teacher Education, 1-15. http://dx.doi.org/10.1177/0022487108322127

Grythe, J. (2011). Forskningsbasert undervisning som evidensbasert praksis? Norsk pedagogisk tidsskrift, 5, 386-397.

Heggen, K., \& Smeby, J.-C. (2012). Gir mest mulig sammenheng også den beste profesjonsutdanninga? (Will high degree of coherence represent the best education? Norsk Pedagogisk Tidsskrift (Norwegian Journal of Pedagogical Research), 96(1), 4-14.

Korthagen, F. (2000). Teacher educators: from neglected group to spearhead in the development of education. In G. Willems, J. Stakenborg \& W. Veugelers (Eds.), Trends in Dutch teacher education (pp. 35-47). Garant: Leuven-Apeldoorn.

Korthagen, F. (2004). In search of the essence of a good teacher: towards a more holistic approach in teacher education. Teaching and Teacher Education, 20, 77-97. http://dx.doi.org/10.1016/j.tate.2003.10.002

Lid, S. E. (2012). R\&D based professional edcation. In Norwegian Organ for Quality in Education (Ed.), (Vol. 1). Oslo: Norwegian Organ for Quality in Education.

Lunenberg, M., \& Korthagen, F. (2009). Experience, theory, and practical wisdom in teaching and teacher education. Teachers and teaching: Theory and practice, 15(2), 225-240. http://dx.doi.org/10.1080/13540600902875316

Malterud, K. (2008). Kvalitative metoder i medisinsk forskning. Oslo: Universitetsforlaget.

Ministry of Education and Research. (2005). The Law for University and University Colleges. Oslo.

Ministry of Education and Research. (2009). White Paper on Teacher Education - The teacher - the role and the education. Oslo: Goverment.

Murray, J., \& Male, T. (2005). Becoming a teacher educator: evidence from the field. $\begin{array}{llll}\text { Teaching } \text { and } \quad \text { Teacher 21(2), } & \text { 125-142. }\end{array}$ http://dx.doi.org/10.1016/j.tate.2004.12.006

Norwegian Organ for Quality in Education (NOKUT). (2010). Evaluation of three vocational degree programmes in Norway. In NOKUT (Ed.). Oslo.

Shulman, L. (1986). Paradigms and research Programmes in the Study of Teaching: A Contemporary Perspective. In M. Wittroch (Ed.), Handbook of research on Teaching. A 


\section{IIMacrothink}

Journal of Educational Issues

ISSN 2377-2263

2015, Vol. 1, No. 1

Project of the American Educational Research Association (pp. 3-36). New York: Macmillan.

Smeby, J.-C. (2007). Connecting to professional knowledge. Studies in Higher Education, $32(2), 207-224$.

Smeby, J.-C. (2011). Profesjonalisering av førskolelæreryrket? (Professionalising of early childhood teachers?). Arbetsmarknad och Arbetsliv (Labor marked and Working Life), 17(4), 43-58.

Stewart, D. W., \& Shamdasami, P. (1990). Focus groups: theory and practice. Newbury Park, CA: Sage Publisher.

Swennen, A., Lunenberg, M., \& Korthagen, F. (2008). Preach what you teach! Teacher educators and congruent teaching. Teachers and Teaching: theory and practice, 14(5-6), 531-542. http://dx.doi.org/10.1080/13540600802571387

Zeichner, K., \& Conklin, H. (2008). Teacher education programs as sites for teacher preparation. In M. Cochran-Smith, S. Feiman-Nemser, J. McIntyre, \& K. Demers (Eds.), Handbook of Research on Teacher Education. Enduring questions in Changing Contexts. Third Edition (pp. 269-290). New York: Rothledgde. 


\section{Macrothink}

\section{Appendix}

Appendix 1. Interview questions

1. What part of the subject of pedagogy do you emphasis?

What knowledge do you think the education students shall have about pedagogical theory and pedagogical practice?

2. How can the subject of pedagogy support educational students understanding of the relation between pedagogical theory and practice?

3. Focus on the educational students you have met, what are they engaged in; theoretical knowledge? Or practical methodological knowledge? Any typical examples?

4. How do you understand research based knowledge?

5. Do you have any examples from your teaching about how to teach research based knowledge?

\section{Copyright Disclaimer}

Copyright for this article is retained by the author(s), with first publication rights granted to the journal.

This is an open-access article distributed under the terms and conditions of the Creative Commons Attribution license (http://creativecommons.org/licenses/by/3.0/). 